\title{
A Fishy Tale of Macrocytosis
}

\author{
Valentin Mocanu BSc${ }^{1}$, Rosario Rebello MD² \\ 'Class of 2016, Faculty of Medicine, Dalhousie University \\ ${ }^{2}$ Department of Medicine, Divison of General Internal Medicine, Dalhousie University
}

\begin{abstract}
Diphyllobothriasis is a rare fish tapeworm infection, yet one of the most important fish-borne human diseases due to the high morbidity and commonly missed diagnosis. It occurs by ingesting infected uncooked fish. Several fish tapeworm species can affect humans, with the most prevalent of these being Diphyllobothrium latum found in pike, perch, and arctic char. In humans, the worm attaches to the small bowel where it can live undetected for 10 to 15 years and can grow as long as 15 meters. While in the small bowel, it competes with the host for vitamin B12, leading to vitamin B12 deficiency and macrocytosis. The signs and symptoms of infestation are often vague and non-specific, making for a challenging diagnosis. Furthermore, physical examination and laboratory investigations are typically unremarkable. We describe only the fourth case report of D. latum in Canada. It occurred in an otherwise healthy patient with a two-year history of vague abdominal pain, diarrhea, low B12, and macrocytosis. The patient was an avid sushi eater and remained symptomatic and undiagnosed during this time. Spontaneous passage of the worm and treatment with praziquantel ultimately led to resolution of her symptoms.
\end{abstract}

\section{Case Presentation}

A 43-year-old woman presented to her family physician with a two-year history of fatigue, diarrhea, and constant dull abdominal discomfort. Stools were described as normal in frequency and intermittently loose in consistency. In addition, she also experienced two to three episodes per month of non-bloody painless diarrhea, which was associated with a cramping abdominal pain. She attributed this pain, which radiated to the back and pelvis, to her menstrual cycle. During this period, she did not have any nausea or vomiting and did not notice any change in weight or appetite.

The patient, a marine biologist with an extensive travel history, noticed that her symptoms began after a busy year of fieldwork in Iceland, Denmark, and the Arctic, during which she began regularly consuming raw sushi and sashimi. She was a nonsmoker and only occasionally consumed alcohol. She was otherwise in good health and did not take any medications or over-the-counter supplements. Her past medical history was significant for a prior myomectomy eight years ago for fibroids. Clinical examination was unremarkable and revealed no neurologic findings or evidence of bruising, bleeding, or stigmata of chronic liver disease.

Initial laboratory investigations yielded the following results: $\mathrm{Hgb} 133 \mathrm{~g} / \mathrm{L}, \mathrm{RBC} 3.6 \times 10^{9} \mathrm{~L}^{-1}$, MCV 101.0 $\mathrm{fL}, \mathrm{MCH} 35 \mathrm{pg}, \mathrm{WBC} 4.7 \times 10^{9} \mathrm{~L}^{-1}$, and platelets 178 x $10^{9} \mathrm{~L}^{-1}$. Serum creatinine, electrolytes, lipase, thyroid and liver function tests were within normal limits. Serum vitamin B12 was 157 pmol/L (N: 156-672 $\mathrm{pmol} / \mathrm{L})$, compared to a level of $435 \mathrm{pmol} / \mathrm{L}$ two years previously. Anti-tissue transglutaminase antibody (IgA normal) was negative, as were tests for Lyme disease and infectious mononucleosis. Due to her significant change in B12 level, she was treated with supplemental vitamin B12 for suspected pernicious anemia. Vitamin B12 levels returned to baseline although she remained macrocytic.

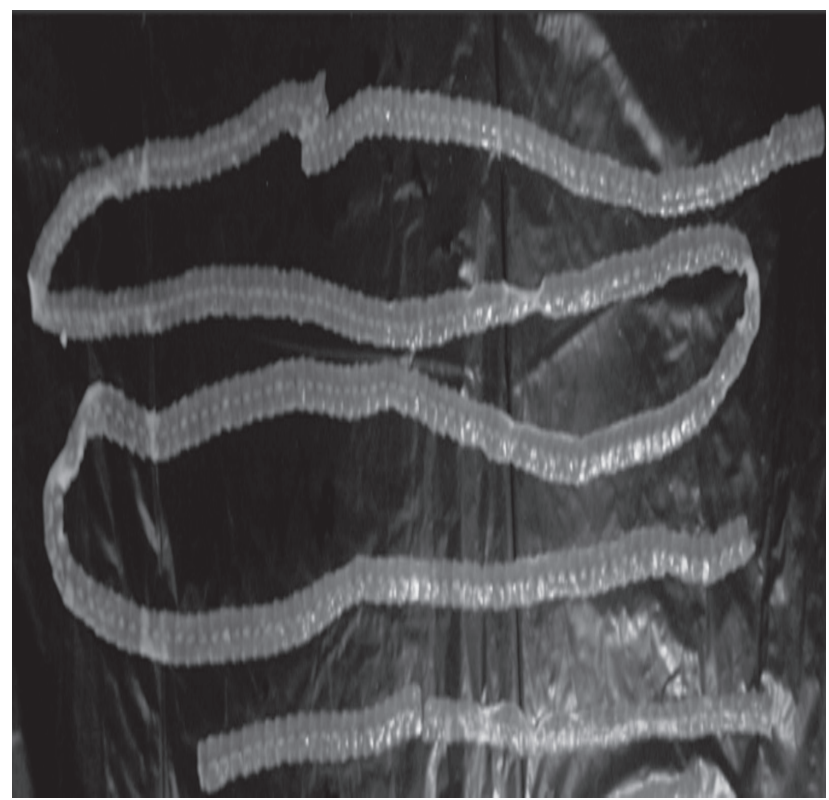

Figure 1. D. latum specimen measuring 1.6 meters collected from patient's stool sample.

Several months later she again experienced painless diarrhea. This time, however, she spontaneously passed a 1.6 meter long tapeworm later identified as 
Diphyllobothrium latum (Figure 1). She was treated with a single dose of praziquantel (10 to $25 \mathrm{mg} / \mathrm{kg}$ and follow-up stool tests for ova and parasites done two weeks later were negative. Investigations several months after she passed the worm revealed that her vitamin B12 deficiency, macrocytosis, and presenting symptoms had resolved.

\section{Literature Search}

All available literature concerning diphyllobothriasis cases in Canada was assessed using the MEDLINE database through the PubMed interface. The literature search was conducted using the terms "diphyllobothriasis OR fish tapeworm AND Canada" and was restricted to the English language and to human subjects. A total of 12 studies were obtained, only three of which contained human case reports of fish tapeworm infestation in Canadians. References of these studies were also reviewed for relevant literature. Results of the search are summarized in Table 3.

\section{Discussion}

\section{Macrocytosis}

Macrocytosis is defined as the average size of red blood cells (RBCs) being greater than normal (MCV $>100 \mathrm{fL})$. It is most commonly seen in the setting of folate deficiency in alcohol abuse, liver disease, and during chemotherapy. However, macrocytosis can have many causes and is categorized histologically into either normoblastic or megaloblastic according to the morphology seen in the bone marrow (Table 1). Cells of normoblastic conformation are characterized by a normal nuclear to cytoplasm ratio indicating unimpaired DNA synthesis. In megaloblastic cells, on the other hand, DNA synthesis is impaired resulting in cells with delayed nuclear maturation and decreased nuclear to cytoplasm ratios. ${ }^{1}$

\begin{tabular}{ll} 
Normoblastic & Megaloblastic \\
\hline Alcohol abuse & Vitamin B12 deficiency \\
Liver disease & Folate deficiency: \\
Hypothyroidism & - poor nutrition (alcoholism) \\
Multiple myeloma & Drugs: \\
Myelodysplastic & - Dihydrofolate reductase \\
syndrome & inhibitors \\
Reticulocytosis & - Anticonvulsants \\
& - Oral contraceptives \\
& - Certain HIV medications \\
\hline
\end{tabular}

Table 1. Causes of macrocytosis
Vitamin B12 deficiency

Folate and vitamin B12 deficiency play a pivotal role in DNA regulation and are the two most common causes of megaloblastosis. ${ }^{2-4}$ Vitamin B12 is obtained from animal dietary sources and has a complicated mechanism of absorption. The acidic milieu of the stomach first facilitates release of dietary B12 from food. Vitamin B12 then binds to an intrinsic factor produced by gastric parietal cells, allowing it to ultimately be absorbed in the terminal ileum. A variety of different factors can interfere with these steps and lead to vitamin B12 deficiency (Table 2)..$^{5}$

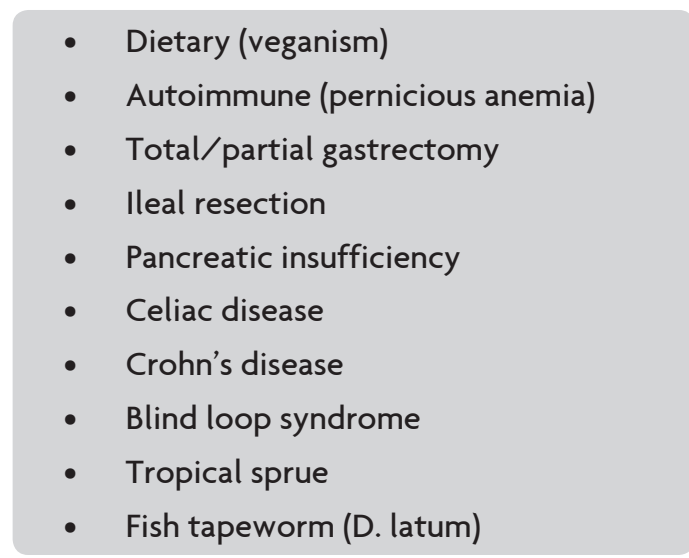

Table 2. Causes of vitamin B12 deficiency

Diphyllobothriasis

Diphyllobothriasis is a clinical syndrome associated with the Diphyllobothrium parasite, and is acquired by ingestion of contaminated raw or uncooked fish. Eggs of D. latum have been found in humans as early as $4000 \mathrm{BC}$ and more than 20 million people are estimated to carry the fish tapeworm. ${ }^{6,7}$ Once prevalent many years ago, diphyllobothriasis rates have since drastically decreased due to modern cooking and fish transport regulations. However, endemic regions still persist in some communities in Northern Europe, Asia, and the Arctic. Furthermore, the increasing popularity of raw fish cuisine like sushi has set the stage for a potential worldwide resurgence of D. latum. ${ }^{8}$ To the best of our knowledge, this is only the fourth case report describing D. latum infestation in Canada and only the second resulting from sushi consumption (Table 3)..$^{9-11}$

Although there are several species that can affect humans, the most prevalent of these is Diphyllobothrium latum found primarily in pike, perch, turbot and arctic char. The life cycle of D. latum involves multiple larval stages and hosts. Worm ova first hatch into embryos in freshwater. ${ }^{10}$ They are then ingested by small crustaceans, or copepods, where they mature 
to the first larval stage. When copepods are ingested by larger fish, the larvae invade fish muscle fibers and mature into the second larval stage called pleroceroids. Consumption by humans of raw fish infected with pleroceroids allows the larva to attach to the walls of the host's small intestine and mature to adult tapeworms within three to five weeks. When mature, D. latum can grow anywhere from two to 15 meters in length making them the longest known human parasites. In humans, the adult parasites continue to grow, release ova, and may live undetected for 10 to 15 years. ${ }^{11,14}$

\section{Symptoms and Investigations}

Diagnosis of diphyllobothriasis is often difficult due to the asymptomatic nature and the subtle findings of the disease. Only $20 \%$ of patients experience any symptoms, which are often mild, non-specific, and can include fatigue, diarrhea, constipation, vague abdominal pain, and headaches. Physical examination and laboratory investigations are typically unremarkable and can further complicate making the diagnosis.

Longstanding infections with D. latum may lead to macrocytic anemia, although the mechanism is not yet fully understood. The anemia is believed to be due

\begin{tabular}{|c|c|c|c|c|c|c|c|}
\hline Reference & Year & Description & Presentation & $\begin{array}{l}\text { Time to } \\
\text { diagnosis }\end{array}$ & Risk factors & Treatment & Resolution \\
\hline $\begin{array}{l}\text { Cushing } \\
\text { and Bacal' }\end{array}$ & 1934 & $\begin{array}{l}\text { Retrospective } \\
\text { observational } \\
\text { study, } 50 \text { cases }\end{array}$ & $\begin{array}{l}39 \text { passed worm } \\
\text { segments in stool, } \\
27 \text { complaints of } \\
\text { vague abdominal } \\
\text { symptoms }\end{array}$ & Unknown & $\begin{array}{l}\text { Jewish } \\
\text { women and } \\
\text { Findlanders, } \\
\text { tasting raw } \\
\text { fish to ensure } \\
\text { proper seasoing } \\
\text { before cooking }\end{array}$ & $\begin{array}{l}\text { Male fern, } \\
\text { kamala, } \\
\text { pelletierin } \\
\text { tannate, and } \\
\text { santonin }\end{array}$ & $\begin{array}{l}\text { Passage of } \\
\text { worm with } \\
\text { intact scolex }\end{array}$ \\
\hline Turgeon ${ }^{13}$ & 1974 & $\begin{array}{l}\text { Retrospective } \\
\text { observational } \\
\text { study, } 9 \text { cases }\end{array}$ & $\begin{array}{l}\text { Asymptomatic, } \\
\text { passage of worm } \\
\text { segments, vague } \\
\text { abdominal } \\
\text { discomfort }\end{array}$ & Unknown & $\begin{array}{l}\text { Raw salted fish } \\
\text { consumption }\end{array}$ & Niclosamide & $\begin{array}{l}\text { Passage of } \\
\text { worm with } \\
\text { intact scolex }\end{array}$ \\
\hline Craig $^{9}$ & 2012 & $\begin{array}{l}\text { Single case } \\
\text { report }\end{array}$ & $\begin{array}{l}\text { Spontaneous } \\
\text { passage of worm, } \\
\text { asymptomatic, } \\
\text { fatigue, } \\
\text { constipation, } \\
\text { vague abdominal } \\
\text { discomfort }\end{array}$ & 8 weeks & $\begin{array}{l}\text { Raw sushi } \\
\text { and sashimi } \\
\text { consumption }\end{array}$ & $\begin{array}{l}\text { Praziquantel } \\
(25 \mathrm{mg} / \mathrm{kg})\end{array}$ & $\begin{array}{l}\text { Stool test } 2 \\
\text { weeks after } \\
\text { passage of } \\
\text { worm revealed } \\
\text { no ova }\end{array}$ \\
\hline
\end{tabular}

to the dissociation of the vitamin B12-intrinsic factor complex in the gut lumen facilitated by the parasite. The worm then preferentially absorbs B12 in a 100:1, ratio making it unavailable to the host. Despite this, low B12 levels are only seen in about $40 \%$ of individuals infected with D. latum, and only $2 \%$ of patients will be clinically anemic. ${ }^{15}$ The distressing spontaneous passage of the tapeworm, as was the case in our patient, is often the only clinical sign of infection. ${ }^{16,17}$ Occasionally, patients may also see segmental chains in their stools. The gold standard for diagnosing D. latum involves using molecular methods to identify ova or worm segments in the stool. ${ }^{11}$

\section{Treatment}

Treatment of D. latum involves a single dose of 10-25 $\mathrm{mg} / \mathrm{kg}$ of praziquantel. Stool specimens are then monitored at one and two weeks for ova, and should be negative after treatment. Otherwise, a second dose of praziquantel is indicated.

\section{Prevention}

Avoiding raw, uncooked or smoked fish is the most effective way to prevent diphyllobothriasis. If uncooked, the Fish and Fishery Products Hazards and Controls Guide recommends that fish be either frozen to a temperature less than $-20^{\circ} \mathrm{C}$ for seven days or to

Table 3. Reported cases of $D$. latum infection in Canada. 
a temperature of less than $-35^{\circ} \mathrm{C}$ for 15 hours prior to consumption. ${ }^{18}$

\section{Conclusion}

Diphyllobothriasis is a fish tapeworm infection that occurs after ingesting infected raw or uncooked fish. In human hosts, the worm competes for vitamin B12 and can lead to vitamin B12 deficiency and macrocytosis. Signs and symptoms are often non-specific, and infection can persist undiagnosed for many years. Although a rare cause of vitamin B12 deficiency, diphyllobothriasis should be considered in the differential for unexplained cases of macrocytosis, as it is a treatable cause of vitamin B12 deficiency.

\section{References}

1. Kaferle J, Strzoda CE. Evaluation of macrocytosis. Am Fam Physician 2009;79(3):203-8

2. Bain B. Haematology a core curriculum. London: Imperial College Press, 2010:15,65.

3. Fernando OV, Grimsley EW. Prevalence of folate deficiency and macrocytosis in patients with and without alcohol-related illness. South Med J 1998;91(8):721-5.

4. Lindenbaum J, Savage DG, Stabler SP, Allen RH. Diagnosis of cobalamin deficiency: II. relative sensitivities of serum cobalamin, methylmalonic acid, and total homocysteine concentrations. Am J Hematol 1990;34(2):99-107.

5. Kaferle J, Strzoda CE. Evaulation of Macrocytosis. Am Fam Physician 2009: 79(3):203-8
6. Chai JY, Murrell KD, Lymbery AJ. Fish-borne parasitic zoonoses: status and issues. Int J Parasitol 2005;35(11-12):1233-54.

7. Reinhard KJ, Barnum SV. Parasitology as an interpretative tool in archaeology. Am Antiq 1991;57:231-45.

8. Dick T. 2008. Diphyllobothriasis: the Diphyllobothrium latum human infection conundrum and reconciliation with a worldwide zoonosis, p. 151-184. In K. D. Murrell and B. Fried (ed.), Food-borne parasitic zoonoses: fish and plant-borne parasites (world class parasites), vol. 11. Springer, London, United Kingdom.

9. Craig N. Fish tapeworm and sushi. Can Fam Physician 2012;58(6):654-

10. Beldsoe GE, Oria MP. Potential hazards in cold-smoked fish: parasites. J Food Sci 2001;66(Suppl. 7):1100-3.

11. Scholz T, Garcia HH, Kuchta R, Wicht B. Update on the human broad tape- worm (genus Diphyllobothrium), including clinical relevance. Clin Microbiol Rev 2009;22(1):146-60.

12. Cushing HB, Bacal HL. Diphyllobothrium latum (fish tapeworm) infestation in Eastern Canada: with particular reference to its increasing prevalence. CMAJ 1934;30(4):377-84.

13. Turgeon EW. Diphyllobothrium latum (fish tapeworm) in the Sioux Lookout Zone. CMAJ 1974;111(6):507.

14. Vuylsteke P, Bertrand C, Verhoef GE, Vandenberghe P. Case of megaloblastic anemia caused by intestinal taeniasis. Ann Hematol 2004;83(7):487-8.

15. Shimizu H, Kawakatsu H, Shimizu T, Yamada M, Tegoshi T, Uchikawa R, et al. Diphyllobothriasis nihonkaiense: possibly acquired in Switzerland from imported Pacific salmon. Intern Med 2008;47(14):1359-62.

16. Lee KW, Suhk HC, Pai KS, Shin HJ, Jung SY, Han ET, et al. Diphyllobothrium latum infection after eating domestic salmon flesh. Korean J Parasitol 2001;39(4):319-21.

17. Bylund, G, Bång B, Wikgren K. Tests with a new compound (Praziquantel) against Diphyllobothrium latum. J Helminthol 1977;51(2):115-9.

18. FDA. 1998. Fish and fisheries products hazards and controls guide. FDA, Washington, DC.

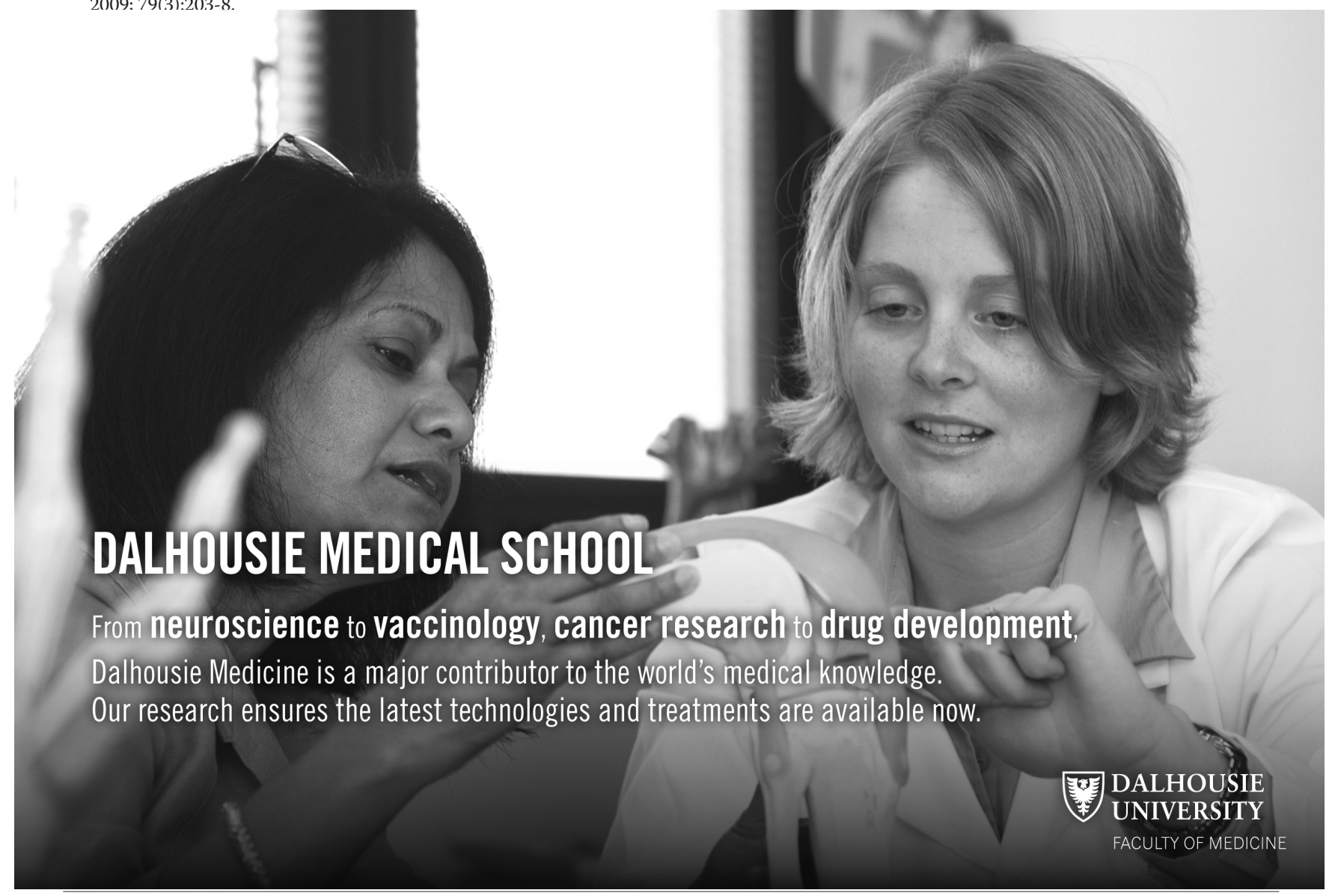

